\title{
RECENT CHANGES IN THE GLACIERS OF SVARTISEN
}

\author{
By W. H. Theakstone \\ (Department of Geography, Victoria University of Manchester, Manchester I3, England)
}

\begin{abstract}
The history of glaciological studies in the Svartisen area is outlined, and observations made by earlier workers are summarized. The present position of the ice limit in the area is indicated and is compared with those of the past. Evidence of extensive, and almost continuous, retreat of the glaciers is presented, and emphasis is placed on the rapidity of the changes since the 1930's. In the present century, the formation of marginal lakes and the detachment of glacier tongues have characterized the decay of many of the Svartisen outlets.
\end{abstract}

RÉsumé. Variations récentes des glaciers du Svartisen. On rappelle l'histoire des études glaciologiques dans la région du Svartisen, et on résumé les observations faites par les chercheurs précédents. La position actuelle de la glace dans cette région est indiquée, et elle est comparée avec les limites antérieures. On a mis en évidence le retrait important et pratiquement continu des glaciers, en insistant sur la rapidité des changements depuis 1930. Le siècle actuel est caractérisé par la formation de lacs marginaux et le détachement de langues glaciaires marquant la regréssion de la plupart des glaciers du Svartisen.

Zusammenfassung. Funge Veränderungen in der Ausdehnung der Gletscher von Svartisen. Es wird eine geschichtliche Übersicht der glaziologischen Untersuchungen im Svartisen-Gebiet und eine Zusammenfassung der Beobachtungen früherer Forscher gegeben. Die gegenwärtige Lage des Eisrandes in dem Gebiet wird mit früheren Lagen verglichen. Der starke und nahezu ständige Rückzug der Gletscher wird aufgezeigt, wobei sich die Schnelligkeit der Veränderungen seit den 3 oer Jahren besonders klar hervorhebt. In diesem Jahrhundert ist der Zerfall vieler der Svartisen-Eisabflüsse durch die Bildung von Randseen und durch die Ablösung von Gletscherzungen gekennzeichnet.

\section{INTRODUCTION}

Svartisen, the second largest ice-covered area of Norway, lies around the latitude of the Arctic Circle, and consists of two plateau ice caps, separated by a deep valley, Glomdalen (Fig. I). When last surveyed, between 1894 and 1905, the ice caps and their outlet glaciers covered $468 \cdot \mathrm{I} \mathrm{km}^{2}$ (Hoel and Werenskiold, $\mathrm{I} 962$, p. $4 \mathrm{I}$ ), but the glacierized area now is less than $400 \mathrm{~km} .{ }^{2}$. Vestisen, the ice cap west of Glomdalen, is slightly larger than Østisen to the east; its highest point, Snetind, rises to I,599 $\mathrm{m}$. The principal peaks of Østisen are Sniptind $(\mathrm{r}, 59 \mathrm{I} \mathrm{m}$.$) , Istind (\mathrm{r}, 577 \mathrm{~m}$.$) and \mathrm{n}$. Kamplitind $(\mathrm{I}, 532 \mathrm{~m}$.$) . Snetind and Istind are nunatak$ mountains, surrounded by ice, whilst Sniptind and $n$. Kamplitind rise directly from Glomdalen. The valley floor falls from about $700 \mathrm{~m}$. in the north-east to about $200 \mathrm{~m}$. opposite the southernmost limit of the ice.

Very few of the glaciers of Svartisen bear names on the I : I00,000 maps published by Norges Geografiske Oppmåling (sheets "Svartisen", "Meløy", "Beiardalen" and "Dunderlandsdalen"), though several are known locally by specific names. For convenience, various of the latter have been adopted here, together with some names used in earlier papers about Svartisen, though these are not recognized officially. Since 1956, a series of expeditions from Cambridge, England has been engaged on glaciological and geomorphological studies at Svartisen. Before this time, only the two north-western outlets had been studied regularly, though isolated observations had been recorded elsewhere in the area since 1873 .

\section{Glacier Behaviour before i87o}

Until the r930's, access to Engabreen and Fondalsbreen, the north-western outlets of Svartisen, was easy, and the glaciers were much visited by tourists at Holandsfjord. Since the end of the nineteenth century, however, the glaciers have been retreating more or less continuously, and now both end a considerable distance from the sea. Rekstad (I9I I) found marine shells in the end moraine beyond Engabreen, and concluded that the ice had advanced to its maximum position over ground which had been covered by the sea in post-glacial time. In I $95^{\mathrm{I}}$, a number of tree stumps were found in front of the glacier, at a location which became ice-free in about ${ }_{1940}$ (Liestøl, 1960 ). As ${ }^{14} \mathrm{C}$ dating indicated the trees to have been 


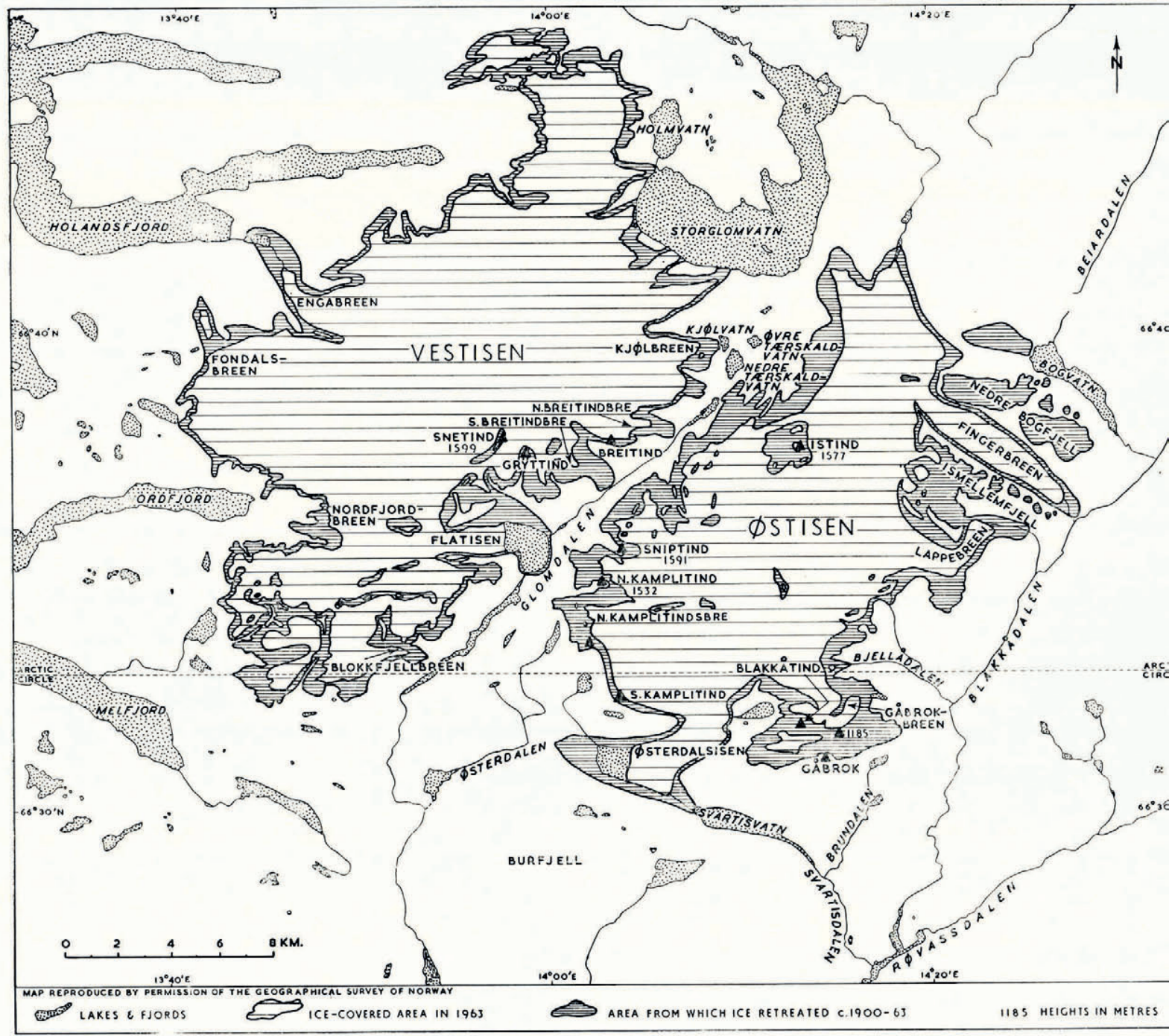

Fig. I. Map of the Svartisen area, showing changes of position of the ice margin during the twentieth century

$35^{\circ} \pm 100$ years old, they must have been snapped by a fairly rapid advance of the glacier in about 1600 . Liestøl considered it likely that no previous advance had reached the area since it was raised above sea-level.

A descriptive poem written at the end of the seventeenth century described the ice as extending "from the highest peaks almost to the lowest shore" (Dass, I958, p. 79); this suggests that Engabreen and Fondalsbreen then terminated a short distance from the sea. About 1720 , an advance of the Holandsfjord glaciers resulted in the destruction of a farm, and growing crops were overridden so quickly that they could not be harvested (Rekstad, I 892). It seems likely that the ice had ended some distance from the farm for a number of years, probably since the buildings were erected. It is generally believed that the glaciers of Norway attained their maximum recent extent about $175^{\circ}$ (Hoel and Werenskiold, r962, p. 6r ). 
An account of about 1805 described Engabreen as ending so close to the shore that it was often washed by the sea during flood tides (Rekstad, 1893). However, in I810, VargasBedemar found that at least seven small, but well-marked parallel moraines could be distinguished in front of the glacier, the outermost a good hundred feet distant from the ice (Vargas-Bedemar, 1819, p. 58). A. Geikie spent some time at Holandsfjord in 1865 , and later stated that, "from the opposite side of the fjord, it seems as if the ample glacier which fills up the bottom sweeps down from the snow-field in a rapid descent to the very edge of the sea. On a visit to the locality, however, it is found that between the foot of the glacier and the sea-margin there lies a plain of shingle and alluvium" (Geikie, I882, p. I43). Engabreen ended in a small lake, which Geikie described as "full of fragments of ice".

\section{Observations made by C. De Seue in i873}

In 1873 , de Seue visited Østerdalsisen, the southernmost of the glaciers of Svartisen; this ended in a lake, Svartisvatn, and large blocks of ice, which had calved from the glacier, floated in the water (Seue, I876). The ice cliffs were about $470 \mathrm{~m}$. wide, and the glacier had advanced some distance since it was photographed in 1870 . Behind the cliffs, the lower part of the glacier sloped steeply down towards the lake (at about 20 degrees), and the surface was very broken; de Seue, who had studied many of the Jostedal glaciers, described the ascent of Østerdalsisen as the most difficult he had ever attempted. However, the central section of the glacier, above the slope to Svartisvatn, was fairly level and free of crevasses. There, below a steep broken ice fall, the glacier divided into two arms, one of which went south-eastwards to Svartisvatn, the other westwards towards Østerdalen.

De Seue measured the movement of the ice along three lines across Østerdalsisen, and found that the velocity varied at different times, a result, he thought, of the steep slope. Although the movement was greatest at the centre, it did not decrease regularly towards the edges. In just over sixty hours, the speed of movement of the ice at a number of points some distance behind the cliffs ranged from $25 \cdot 4 \mathrm{~cm}$./day to $55^{\mathrm{I}} \cdot 2 \mathrm{~cm}$./day. Movement measured in short periods of time throughout a two-day spell was jerky and irregular, and a backward movement was recorded at one time. In view of the heavily crevassed nature of the glacier, de Seue did not consider this surprising.

\section{Observations made by C. Rabot, i88 I-84}

Between I88 I and I884, the Svartisen area was explored by Rabot, who produced the first detailed map of the region (Rabot, I898). In I88I, he found that Østerdalsisen had deposited a series of $4^{-5} \mathrm{~m}$. high moraines in Svartisvatn, and had retreated to about the position that it had occupied in I870. In 1882 , he examined the glacier from Burfjell, at its southern side, and noted that the arm going towards Østerdalen was longer than that towards Svartisvatn (Fig. 2). Rabot called at Holandsfjord in I88 I and noticed the false impression still gained by a distant view of the glaciers there; although Engabreen appeared to reach the sea, the ice and the fjord were separated by a very low plain about a kilometre long. Rabot estimated that the glacier, with which five small moraines were associated, was $7 \mathrm{~km}$. long and I $\mathrm{km}$. wide. Nearby, Fondalsbreen, dominated by two zones of seracs, was $70 \mathrm{~m}$. wide at its lower end. On returning to these glaciers two years later, Rabot (1899) found that Fondalsbreen had retreated $10 \mathrm{~m}$., and Engabreen rather less. The retreat continued in the following two years.

Rabot (r 898, r935) published the first descriptions of many other glaciers of Svartisen. In $\mathrm{I}_{882}$, he saw a single ice stream $5^{-6} \mathrm{~km}$. wide, which descended from Vestisen to the lake Storglomvatn; many icebergs floated in the lake. A few days later, he noted two very flat glaciers occupying a depression leading down to Bogvatn, the lake at the north-eastern border of Østisen. Further south, two major glaciers descended to Blakkådalen, the valley running 
south-westwards from Bogvatn. The first, Fingerbreen, which almost reached the river Blakkåga, was $\mathrm{I}, 500 \mathrm{~m}$. wide at its lowest end, and the second, Lappebreen, 700-80o m. Both had steeply sloping fronts, though the general gradient of Fingerbreen was gentle. Lower down Blakkådalen, Rabot saw three glaciers at the head of the tributary valley Bjellådalen. After walking back to the coast, he visited Nordfjord, north of Melfjord, which had at its head a short valley terminated by an impressive cirque, through which a crevassed glacier, Nordfjordbreen, descended. Ice from the broken tongue reunited below to form a strongly convex reconstituted glacier, which ended 50-6o m. above sea-level. Nearby, a glacier descended the sheer cliffs at the northern side of the fjord to a position only a few metres above the sea.

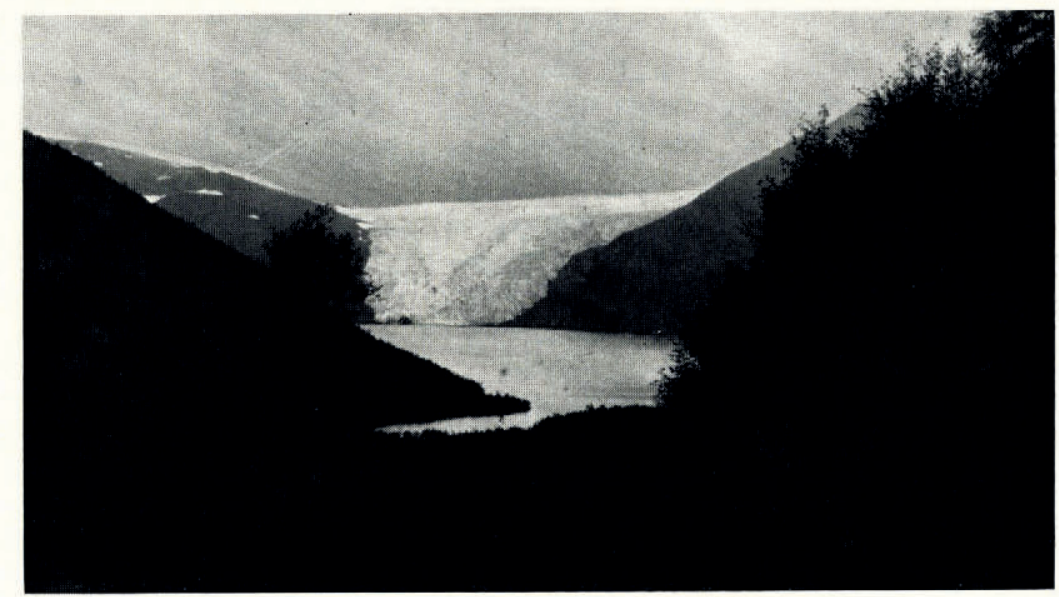

Fig. 2. The eastern arm of Østerdalsisen, from east of Svartisvatn, 13 August 1882. (Photograph by C. Rabot)

\section{Observations made by J. Rekstad, i89o and i89i}

Rekstad (1892, I893, I 900 ) made many observations of the glaciers of Svartisen in 1890 and $189 \mathrm{I}$, when on a geological reconnaissance of part of the area. In 1890 , Engabreen still ended in a lake, and lay partly in contact with a terminal moraine. The ice in the basin there, 40-50 m. thick, descended to about $20 \mathrm{~m}$. below sea-level. A gravel ridge, about $10 \mathrm{~m}$. high, stood at the seaward side of the lake, and two smaller moraines were situated between it and the fjord. The outermost of these, $400 \mathrm{~m}$. from the glacier, was separated from the sea by a gently sloping plain $400 \mathrm{~m}$. long. Rekstad found the maximum speed of movement of Engabreen to be $172 \mathrm{~cm}$./day, at about $55^{\circ} \mathrm{m}$. above sea-level, some $45^{\circ} \mathrm{m}$. below the snow line. Fondalsbreen ended at a height of $86 \mathrm{~m}$. above sea-level,* about $3.5 \mathrm{~km}$. from the sea. A $70 \mathrm{~m}$. high terminal moraine bordered the fjord, and four lesser ones were situated between it and the ice. The $4 \mathrm{~km}$. long glacier was $\mathrm{I}, 000 \mathrm{~m}$. wide in its upper part, but narrowed considerably as the surface slope increased towards the lower end of the tongue. Large transverse crevasses cut the lower part of the glacier, and the small section below was marked by five broad white bands parallel with the foliation (Blaublätter-struktur); Rekstad believed that the bands had originated when snow fell into crevasses during the winter and the crevasses closed later, lower down the glacier.

Rekstad crossed Vestisen to Snetind in 1890 , and saw a small rock outcrop at the north

* The heights of various permanent features determined by Rekstad in 1890 and 1891 do not coincide exactly with those recorded later on the 1 : 1 0o, ooo topographic maps published by Norges Geografiske Oppmåling. 
side of the long Snetind ridge. Later, he walked up Glomdalen, where the lowermost glacier descending from the north-west, Blokkfjellbreen, did not reach right down to the valley bottom. The gradient of the lower part of this glacier was about 20 degrees, and Rekstad mentioned that, although the tongue resulted from the junction of two arms near the plateau edge, there was no medial moraine. In 1890 , Flatisen, the principal outlet of central Svartisen, which occupies a deep hollow in Vestisen, extended across Glomdalen, and spread out there in a fan-like manner to north and south. A small lake was dammed by the northern border of the ice below a waterfall in the bottom of Glomdalen. Icebergs floated in the lake, and the river Glomåga ran through it to a sub-glacial depression, emerging at the foot of the $20-30 \mathrm{~m}$. high cliffs of the southern side of Flatisen. At its lowest part, the glacier was $1,500 \mathrm{~m}$. wide, and was traversed by large crevasses, which prevented walking on the ice. The adjacent rock wall was extremely steep, so that it was very difficult to pass Flatisen en route up Glomdalen. Rekstad estimated that the ice at the bottom of the valley was at least $100 \mathrm{~m}$. thick. In $\mathrm{I} 89_{\mathrm{I}}$, he ascended the glacier to its head above Nordfjord, and found that the average gradient of its 7-8 km. long course was 4.5 degrees. Higher up Glomdalen, above Flatisen, four small glaciers descended from the west towards the valley floor. The ice-free area of the valley was a narrow gap between the ice masses, and the eastern side was so steep that, at certain places, ice avalanched into the river. At the upper end of Glomdalen, Kjølbreen, descending from Vestisen, extended some distance out into the lake Kjølvatn.

In $\mathrm{I} 89^{\circ}$ and $\mathrm{I} 89 \mathrm{I}$, Østerdalsisen still reached the edge of Svartisvatn, though the tongue did not extend far enough into the lake for calving to occur. The slope to Svartisvatn was approximately 20 degrees, about the same as in 1873 , and the central part of the glacier still was comparatively flat. In 1890 , Rekstad was shown a large stone $15 \mathrm{~m}$. above the glacier's surface at the north-western side of Østerdalsisen, and was told that, twenty years before, the ice had reached the stone. From a distance, Rekstad noticed a large, delta-like flat of sand and gravel at the end of the glacier's western arm.

In 1890 , Fingerbreen descended from the north-west into Blakkådalen with an even slope of about 5 degrees for "as far as the eye could see from the valley". Although there was a short space between the end of the glacier and the Blakkåga, moraines indicated that the ice had formerly reached the river. Nearby, Lappebreen descended to $390 \mathrm{~m}$. above sea-level. Rekstad recorded that this glacier had two arms, one coming from the south-west, the other from the north-west, but that there was no medial moraine. The lowest part of the glacier was about $600 \mathrm{~m}$. wide. In Bjellådalen, a glacier descended from the head of the valley to a height of $320 \mathrm{~m}$. above sea-level; most of the ice avalanched over the rock. Although large moraines indicated that the ice had extended $2 \mathrm{~km}$. further in the past, the existence of large birch trees between the glacier and its moraines suggested to Rekstad that this had not been the case within the preceding hundred years. To the south of Bjellådalen, the ice hung above the sides of Brundalen, though no glaciers descended to this valley in I89o. Nordfjordbreen, seen by Rekstad a few days after his journey through Blakkådalen, descended from the northeast to a height of $90 \mathrm{~m}$. above sea-level. The ice flowed over the ridge around the inner part of the fjord; much of it avalanched with crashes audible at a distance of about $8 \mathrm{~km}$. Below the ice fall, the glacier was $1,55^{\circ} \mathrm{m}$. long, and it terminated about $2 \mathrm{~km}$. from the sea. Eleven distinct dirt zones, spaced fairly regularly, were parallel to the foliation on the lower tongue. Rekstad believed that the dirt indicated the ice that had descended the fall in summer, the intervening comparatively clean ice having descended during the winter. He calculated that, as the ice had taken eleven years to move from the ice fall to the end of the glacier, the mean rate of movement was $\mathrm{I}_{4} \mathrm{I} \mathrm{m}$./year. This part of the glacier, which was of considerable size, was free from crevasses despite an average surface slope of about 20 degrees. In I 89 I, Rekstad found that the glacier to Storglomvatn had divided into two separate branches since Rabot's visit in I882. Both arms reached the lake, though neither extended to particularly deep water, and numerous small icebergs floated in Storglomvatn. 
Glacier Behaviour i 889-i 909

Between I889 and I 898, Kaiser Wilhelm II measured a retreat of 6o-80 m. at Engabreen (Rabot, 1899 , p. 340), and in 1898 , Rabot was informed by a local farmer that the glacier had been retreating continuously for fifteen years. In the same year, the Prince of Monaco set up two cairns at the glacier, one $63 \mathrm{~m}$. from the ice, the other ro $\mathrm{m}$.; the nearer of these was destroyed in 1905 as the glacier advanced (Rekstad, I9 I I). Rekstad believed the advance to have begun in 1903 , in which year Kaiser Wilhelm II erected two further cairns. In Igog, Rekstad found that the ice front had advanced about roo $\mathrm{m}$. towards the 1903 cairns, to a position $45 \mathrm{~m}$. from the remaining 1898 cairn; the glacier was about $\mathrm{r} 8 \mathrm{~m}$. in advance of its I 898 position (Fig. 3). During the advance of Engabreen, in about I9o4, the course of the melt stream from the glacier was altered, and the lake which had formed at the ice front became filled with sediments in only five years (Rekstad, I912). In Igog, Fondalsbreen was a little further forward than it had been in I883, having advanced about $60 \mathrm{~m}$. between 1907 and 1909 (Rekstad, I9I I).

Svartisen was surveyed by Norges Geografiske Oppmåling between I894 and I905. The survey parties made a number of notes about the glaciers (Paulsen, unpublished), though no attempt was made to differentiate between ice and permanent snow on the

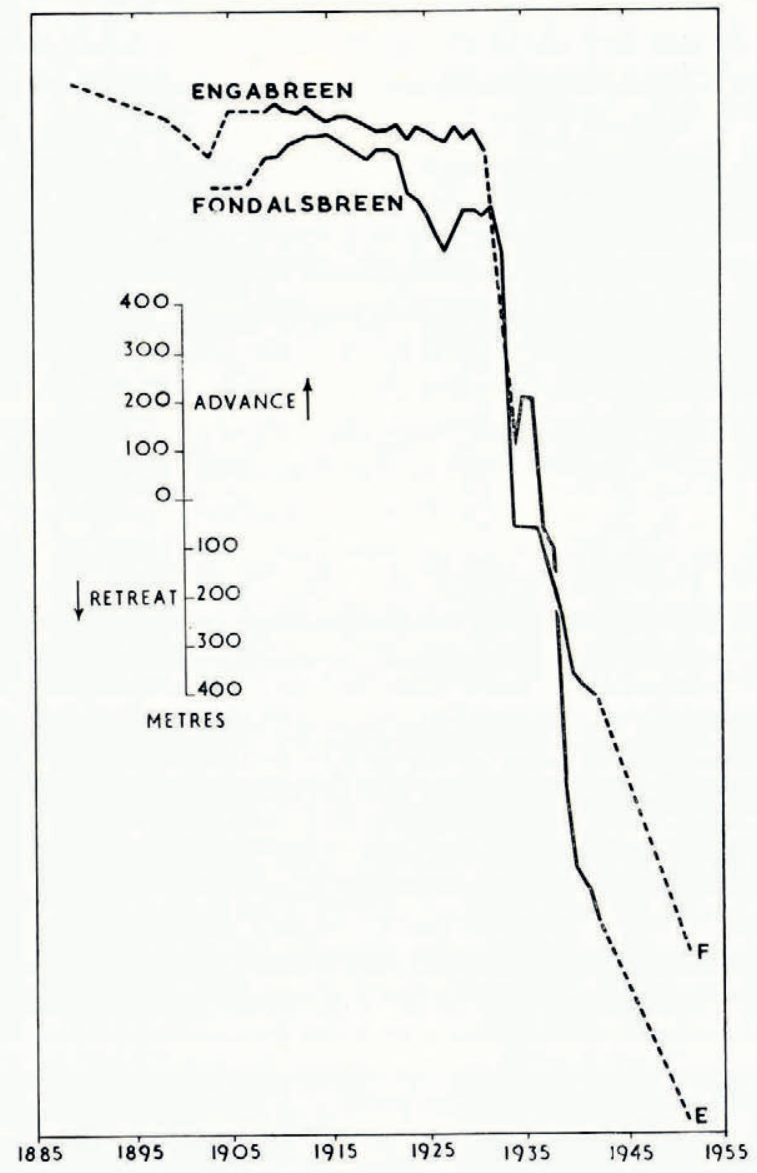

Fig. 3. Variations of the Holandsfjord glaciers, $I 889-1951$ 
I : Ioo,ooo topographic maps produced. The eastern arm of Østerdalsisen just reached Svartisvatn in 1897, and a small lake had formed in front of the western arm; Rekstad had made no reference to such a lake after his visit of 1891 . In 1896 , the survey party found that Fingerbreen did not quite reach the Blakkåga, though moraines indicated that it had done so not long before. According to Lapps, the glacier had extended $300 \mathrm{~m}$. further to the east not more than $150 \mathrm{yr}$. earlier. At the lowermost bend of Lappebreen, a small lake had formed between the side of the main glacier and the front of the tributary which descended from the northwest. The ice stream above Storglomvatn had divided further between I $89 \mathrm{I}$ and I 898 , when three glaciers descended to the lake from the south-west, and a fourth one just reached it from the west.

\section{Observations made by R. Marstrander in igio}

Marstrander ( I9I I [a], [b]) made a close study of many of the Svartisen glaciers in r9 Io, while carrying out a programme of geological mapping. Osterdalsisen was then broken by deep crevasses, especially near the borders, and melting was proceeding very quickly. Morainic material was almost completely absent from the eastern arm of the glacier, and Marstrander, having crawled far into some of the large gaps between the ice and the underlying rock, reported that the bottom there also was very clean. The glacier terminated about $5^{\circ} \mathrm{m}$. from Svartisvatn, and the surface slope of the eastern outlet was about i 2 degrees. The centre of the glacier was still relatively flat, and the $3-4 \mathrm{~km}$. long western branch sloped at a mere 2 degrees. This latter part of the glacier was $1,500 \mathrm{~m}$. broad, and it calved steadily into the lake in which it ended. The lake was noticeably larger than shown on the 1897 map; a local farmer informed Marstrander that the glacier there had retreated $300-400 \mathrm{~m}$. within the previous twenty years. On Burfjell, above the southern side of Østerdalsisen, there was a prominent vegetation-covered moraine, $4 \mathrm{~km}$. long, 50-10o $\mathrm{m}$. from the ice edge.

Flatisen was heavily crevassed in I9Io, principally as a result of the great increase of width about half-way down its course. Although the general slope along the surface was only about 3 degrees, the central section was too broken to permit walking there; the only routes up the glacier were very close to the sides. The best was at the northern side, where a wide lateral moraine stretched about $2 \mathrm{~km}$. up-glacier from the end. Marstrander considered that this resulted largely from avalanching of material on the high, steep rock wall past which the glacier flowed. At the southern side, the glacier flowed at the base of another steep rock wall, and a $100-150 \mathrm{~m}$. high moraine lay along the border. A medial moraine indicated the junction between the main ice stream, descending from the head of the glacier, and that of the northern tributary ice fall south-west of Snetind. Dirt cones were present at several places near the front of the glacier. Marstrander found that Flatisen still extended right across Glomdalen, but that it no longer spread out fan-like up and down the valley; there was only a slight outlet towards the south (Fig. 4). The northern outlet noted by Rekstad twenty years before had disappeared completely, and the surface of the glacier nowhere reached the level of the top of the Glomåga waterfall; it was clear that Flatisen had retreated considerably during the preceding years. The glacier calved into the lake below the waterfall, and the Glomaga continued beneath the ice to emerge with the melt stream through a semicircular opening at the southern side.

Fingerbreen, the second largest glacier of Svartisen in 1910 , had an average slope of about 5 degrees, and was so broken - particularly in the lowermost two kilometres - that walking on it was impossible. Access to the upper part of the glacier could be gained only by way of the valley side. Once there, it was necessary to keep to the southern edge, to avoid the chaos at the northern side. Great changes had occurred within the firn area since the survey was made a few years earlier. A nunatak, about $100 \mathrm{~m}$. long, $30 \mathrm{~m}$. wide and $6-7 \mathrm{~m}$. high, was visible just west of the northern valley wall, and a smaller one could be seen further south. The 
tongue of the glacier ended about $200 \mathrm{~m}$. from the Blakkåga, and the melt stream emerged at the northern side and ran round the border, in places flowing back beneath the ice. The lower part of the tongue was $700 \mathrm{~m}$. wide, only half the size noted by Rabot in I882; the terminal moraine was several metres high. The southern edge of the lowermost third part of the glacier was covered by a lateral moraine, with a steep inner slope and a gentle outer one partly colonized by birch scrub and grass. The small glaciers on the neighbouring valley side appeared to have increased in size since the 1896 survey, and two of them descended as far as the main glacier itself.

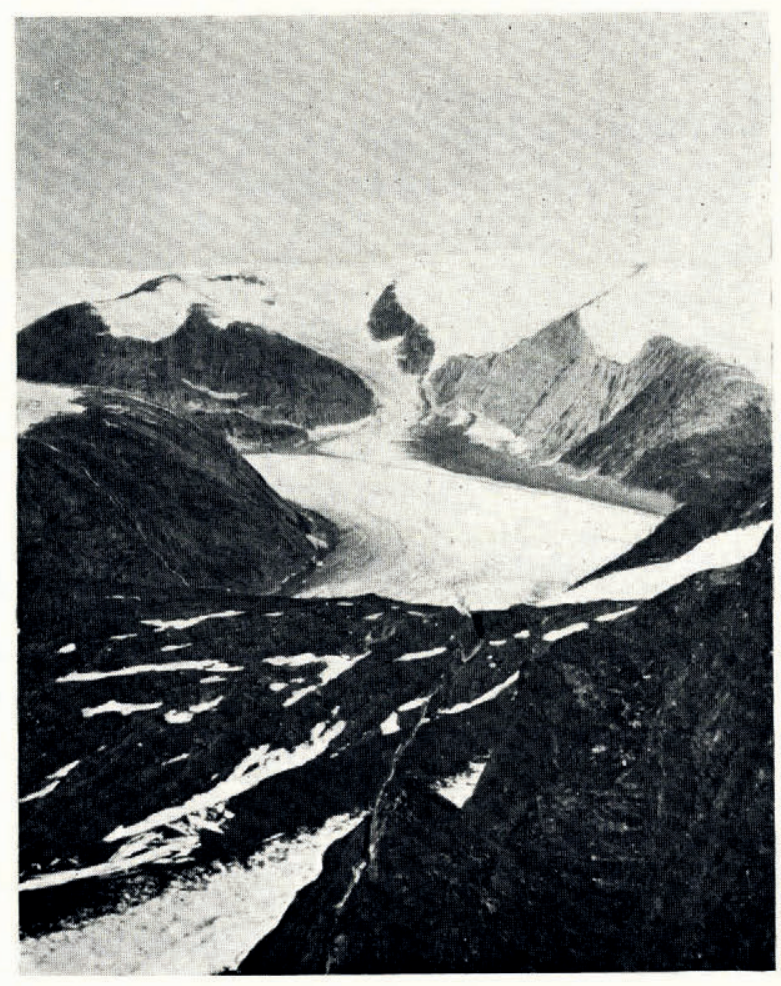

Fig. 4. Flatisen from the south-east, August 19Io. The upper limit of the morainic material (grey) above the northern side of the glacier is the "I750 trim line". Lateral and medial moraines are evident. The highest point on the skyline is Snetind $(I, 599 \mathrm{~m}$.$) ; Gryttind lies to the right. In the middle distance (right), n. Kamplitindsbre descends towards Glomdalen.$ (Photograph by R. Marstrander)

Marstrander reported that Lappebreen twice swung through a right angle. As the uppermost bend coincided with a steep slope, that section of the glacier was impassable. However, the lower part of Lappebreen was uncrevassed, and there was no difficulty in walking upon it. There was no moraine on the glacier, perhaps because gaps up to $\mathrm{I} \cdot 5 \mathrm{~m}$. wide occurred between the ice and the adjacent rock walls. The corrie glacier which had joined the main ice stream at the lower bend in 1896 had retreated $800 \mathrm{~m}$. towards the bottom of the corrie by 1910 . The stream from Lappebreen emerged from the centre of the ice front, and entered a $15 \mathrm{~m}$. deep gorge only $100 \mathrm{~m}$. from the glacier.

The glacier at the innermost end of Bjelladalen in I9 1o descended right to the bottom of the valley by way of a $\mathrm{I}, 000 \mathrm{~m}$. ice fall. At the south-western limit of Svartisen a glacier (Gåbrokbreen) descended some distance to the north of the mountain Gåbrok. Ending in an 
arched, bulging front, the glacier everywhere exhibited a close but distinct banded structure. Crevasses were almost exclusively longitudinal, and the ice could be crossed without difficulty. An outer end moraine lay $60 \mathrm{~m}$. from the glacier, which was connected with a nearer moraine, $30 \mathrm{~m}$. distant, by an "ice floor", about $30 \mathrm{~m}$. broad, which curved regularly to the ice front. A similar feature was present just west of the summit of Gåbrok, where the firn curved smoothly over a steep descent in a crevasse-free arch to a flat plateau; there it continued to an end moraine by way of a $100 \mathrm{~m}$. broad "floor". Marstrander thought that, though the slight slope of the glacier fronts probably showed them to be retreating, the bulge behind might indicate a readvance. Much ice had melted from the Gåbrok area between I 896 and I 910 . In the earlier year, the ice edge was $\mathrm{I} \mathrm{km}$. from a summit I, I $85 \mathrm{~m}$. high, but by I9Io it was only $200 \mathrm{~m}$. away, and a ridge had been uncovered to the east. Another ridge was appearing in several places between "I, I 85 " and Blakkåtind, and the Blakkåtind ridge itself was far longer than in 1896 .

The ice from Vestisen in 1910 descended towards Storglomvatn as a single stream for a considerable distance, dividing into four only about $300 \mathrm{~m}$. above the lake. Of the four separate glaciers, the central two descended "almost vertically" into the water, so that many calves broke from their heavily crevassed tongues. The outer two glaciers had a lesser slope. At the northern end cf Glomdalen, the steep-fronted Kjølbreen calved over a width of $300-400 \mathrm{~m}$. in Kjølvatn; the glacier presented an easy route to Vestisen. At the opposite side of the valley, the glacier which descended from Østisen to nedre Tærskaldvatn had increased in size since it was photographed in $\mathrm{I} 8 \mathrm{~g}_{\mathrm{I}}$ (Fig. 5). Further south, two glaciers descended to Glomdalen from around Breitind; n. Breitindbre ended only I $\mathrm{m}$. from the Glomåga, and s. Breitindbre went right out into the river. South of $n$. Kamplitind, n. Kamplitindsbre had retreated to a position $80 \mathrm{~m}$. within the slope over which it had descended in 1897 . The small rock outcrop noted north of Snetind in I 89 I by Rekstad was no longer visible when Marstrander ascended the mountain. Marstrander reported that signs of a new advance were evident at a number of small, steeply sloping glaciers, though not at the major trunk glaciers.

Marstrander stated that the firn limit, which varied between $800 \mathrm{~m}$. and I, $100 \mathrm{~m}$., was lowest at the northern part of Vestisen and in the hollow above Nordfjord which fed Flatisen. He believed that the smoother features of Vestisen indicated that the ice there was thicker than at Østisen, where the underlying rock influenced the form of the upper surface. In addition to fourteen major glaciers at Svartisen, Marstrander identified forty-five hanging glaciers and

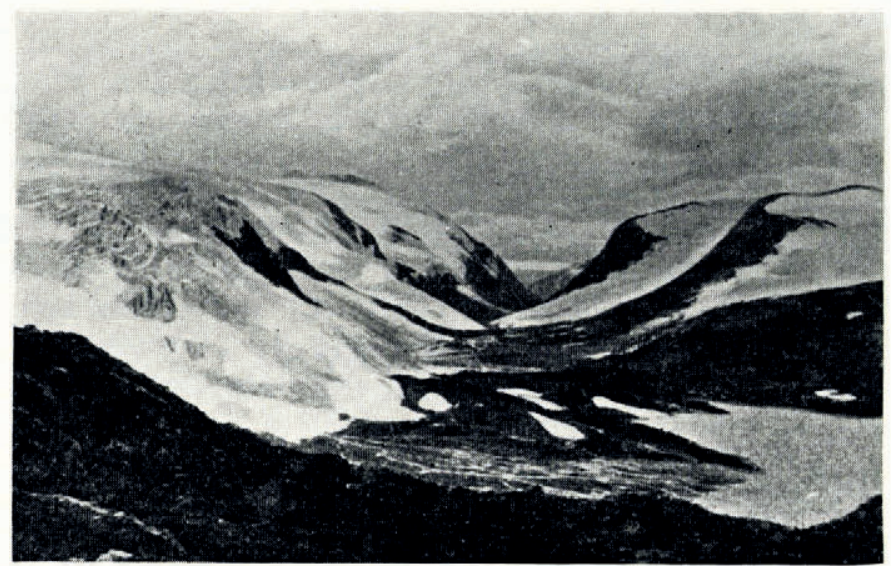

Fig. 5. Glomdalen from above nedre Tarskaldvatn, 24 August 1910. The glaciers below Istind descend to the bottom of the valley (left), as does $n$. Breitindbre right, middle distance). Sniptind $(I, 59 I \mathrm{~m}$.$) is visible on the skyline left of the valley.$ (Photograph by R. Marstrander) 
"gully glaciers" between I km. and $3 \mathrm{~km}$. in length. Furthermore, the firn itself almost everywhere moved out towards the steep slopes, so that ice and snow avalanches frequently broke away and fell into the valleys. Often, so much material was discharged in this way that it did not melt, but remained as a large ice scree or fan in which the big ice blocks were partly frozen together.

\section{Glacier Behaviour i 9 i I-40}

Oxaal set up cairns at Østerdalsisen in I9I3, and Rekstad (I9I5) recorded that the eastern arm of the glacier retreated $8 \mathrm{~m}$. during the year which followed. Between 1925 and I935, a number of ski-ing trips were made across Svartisen, and some observations about the glaciers were printed. In 1925, an easy route down Flatisen was found at the northern side of the glacier, but the remainder of the lower part was very heavily crevassed, and the ice ended in steep, high cliffs (Rygh, I935, p. I39). The Glomåga then flowed past the lower border of the glacier. In 1932, one or two glaciers still projected into Storglomvatn, and several icebergs floated in the lake. In I934, there were still three ice falls at Fondalsbreen, descending a total distance of about $\mathrm{I}, 000 \mathrm{~m}$. (Jensen, 1935, p. I 52).

Rekstad recorded annual measurements of the fluctuation of Engabreen and Fondalsbreen each year from 1909 to $193^{2}$ in Bergens Museums Arbok. From 1933 until 1939, the observations were recorded in the same periodical by Fægri. Measurements were made annually until I943 (Fægri, [1950]). Between I909 and I93I, the overall retreat of Engabreen was about 7 I $\mathrm{m}$., although a number of slight re-advances were recorded in the period (Fig. 3). In the autumn of $193 \mathrm{I}$, however, the glacier began to break up, and to calve across the entire width of its front (Fægri, I935). By the following autumn the whole of the lower part of the glacier was floating: a photograph taken in $193^{2}$ by Richter (1936) shows calves as long as $200 \mathrm{~m}$. floating in the lake. Between $\mathrm{I} 93 \mathrm{I}$ and $\mathrm{I} 934$, the end of the glacier retreated $6 \mathrm{I}_{2} \mathrm{~m}$., and although an advance was recorded during the following year, continuous rapid retreat was characteristic of the rest of the period. The depth of the lake at the end of Engabreen increased from $20 \mathrm{~m}$. at the 1909 position of the ice front to more than $40 \mathrm{~m}$. at the 1934 position, and to $96 \mathrm{~m}$. at the 1939 position. In 1933-34, the lower part of Fondalsbreen, which earlier had formed a thin, stagnating tongue in a deep gorge, melted away, and a retreat of 500-600 $\mathrm{m}$. was recorded for the year. The glacier was left in a hanging valley, and in 1934 it terminated at the top of a roo m. high precipice (Fægri, I 935).

Lundqvist studied Østerdalsisen and Flatisen in 1935 (Granlund and Lundqvist, 1936). The eastern branch of Østerdalsisen then terminated in a deep gorge about $700 \mathrm{~m}$. from the shore of Svartisvatn (Fig. 6). From the evidence of photographs and the topographic map, Lundqvist calculated that the mean annual surface ablation of the glacier between 1897 and 1935 had varied from about $\mathrm{I} \cdot 5 \mathrm{~m} . / \mathrm{yr}$. at $375 \mathrm{~m}$. above sea-level to about $4.3 \mathrm{~m} . / \mathrm{yr}$, at $175 \mathrm{~m}$., the approximate height of the snout in 1935 . Flatisen reached only half-way across Glomdalen, and had become much thinner since Marstrander's visit in rgio (Fig. 7). Lundqvist calculated that the mean rate of ablation of the glacier surface between 1897 and 1935 was about $1 \cdot 7 \mathrm{~m}$./yr. The glacier which descended towards the top of the Glomaga waterfall from east of the peak Gryttind also had become much smaller, and was almost out of sight from the valley bottom south of Flatisen. To the south, Blokkfjellbreen had retreated considerably in the years preceding $\mathbf{1 9 3 5}$.

The annual retreat of Nordfjordbreen between 1935 and 1940 was recorded in Bergens Museums Arbok. The total for the period was $5 \mathrm{I}$ I m., a retreat of $379 \mathrm{~m}$. taking place between 1937 and 1939. Rogstad (1942) calculated the thinning of Svartisen between 1920 and 1940 by comparing discharges of glacial rivers with those of neighbouring non-glacial ones. He found that the height of the entire glacier area supplying the outlet from Storglomvatn must have diminished by $18 \mathrm{~m}$., three-quarters of the total occurring in the period $19^{29-39}$. 


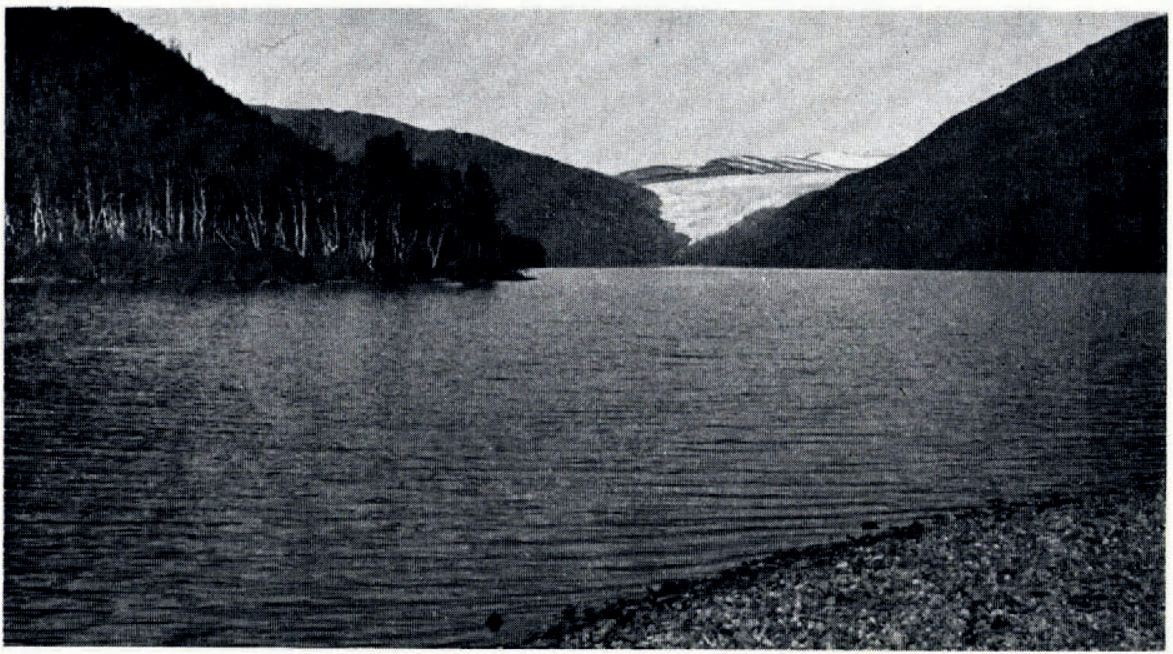

Fig. 6. The eastern arm of Østerdalsisen, from the eastern shore of Svartisvatn, 22 August 1935. (Photograph by G. Lundqvist)

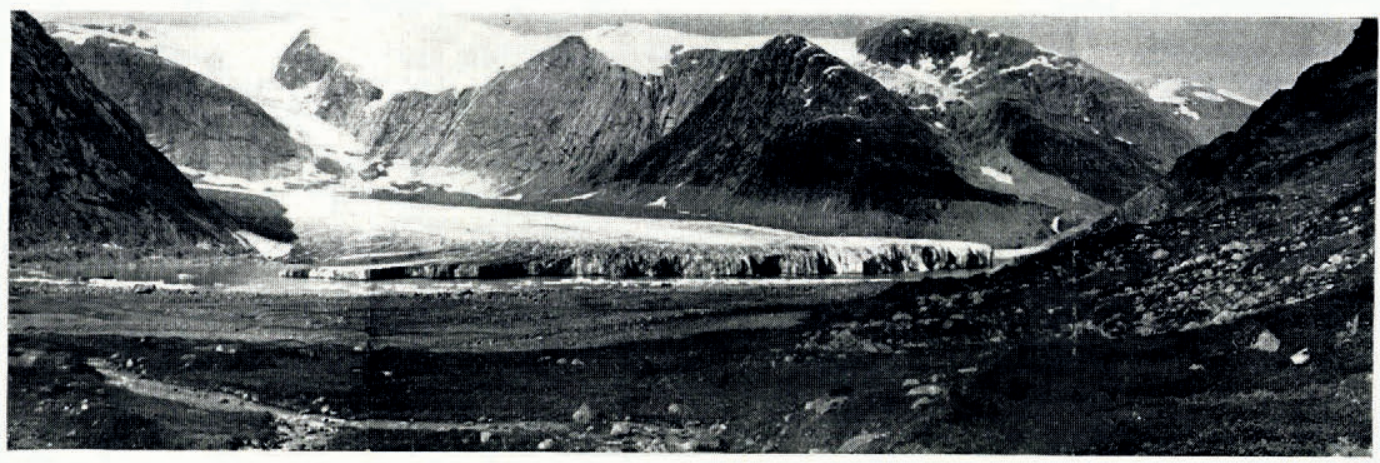

Fig. 7. Flatisen from the bottom of Glomdalen, 18 August 1935. The river Glomaga runs through the lake in front of the glacier. Marked retreat of the ice in the area occurred in the preceding quarter century. (Photograph by G. Lundqvist)

Glacier Behaviour i 94 I-56

In 194 I a great flood burst down Svartisdalen and caused severe damage in the valley beyond. Engineers from the State Water Authority (Norges Vassdrags- og Elektrisitetsvesen) found that the lake dammed by the western arm of Østerdalsisen had enlarged greatly since the last recorded observation, and that it had drained recently. The glacier adjacent to the lake was so crevassed that walking there was not possible. In August 1942, the lake had refilled, and was draining normally to Østerdalen. Its northern margin then was about $\mathrm{I} \mathrm{km}$. long, and its southern margin $2 \mathrm{~km}$. The lake extended beneath the glacier, and many icebergs floated in it. Later in the summer, the water again flooded beneath the ice to Svartisdalen. Drainage by way of a subglacial course occurred each summer, and in 1949 the level of the ice-dammed lake fell by $40 \mathrm{~m}$. (Holmsen, 1949). In $\mathrm{r} 954$ the lake level fell $57 \mathrm{~m}$., to a height only $6 \mathrm{~m}$. above that at which the water emerged at the head of Svartisdalen; the surface of the lake then was entirely obscured by icebergs. A photogrammetric survey was made in I954, and a map of the glacier and lake was prepared. This showed that the eastern outlet 
ended about $500 \mathrm{~m}$. behind its 1935 position, and that the western outlet ended in high cliffs $2,600 \mathrm{~m}$. behind the position occupied in 1897 . Both the northern and southern shorelines of the lake were about $3 \mathrm{~km}$. long (Liestøl, 1956). Because of the increasing flood damage caused each year, Norges Vassdrags- og Elektrisitetsvesen initiated the excavation of a relief tunnel through the bedrock underlying Østerdalsisen, beginning in 1955 at the head of Svartisdalen. From 1947 until I 957 a local observer, Karl Westermark, measured the changes of position of the ice edge on the bare rock of Burfjell. The total down-slope measurement for the ten-year period, I I $2 \mathrm{~m}$., represented a change of $107 \mathrm{~m}$. in the horizontal direction. The average rate of retreat was rather less than that measured at the eastern end of the glacier for the period $1949-52$, during which recession of the tongue totalled $62 \mathrm{~m}$. (Bergersen, unpublished.)

In $195^{\circ}$ and $195 \mathrm{I}$, Bergersen (unpublished) carried out glaciological studies in the Holandsfjord area. By then, the lower part of Fondalsbreen had become detached, and resembled a regenerated corrie glacier fed by steady avalanching from above. Engabreen, which was very clean, though having a well-developed "sole" about $20 \mathrm{~cm}$. thick, had retreated about $400 \mathrm{~m}$. since 1943 . The end of the glacier had finally left the lake basin above Holandsfjord in 1944, after occupying it for at least eighty years. Between rgog and 195I, Engabreen retreated about $2 \mathrm{~km}$. (Fig. 3), and in I95 I the firn line lay at I, IOO-I,200 m. In I950, Bergersen found that the nunatak north of Snetind, seen by Rekstad in I 890 but hidden when Marstrander was there in 1910 , again was visible; it was $100 \mathrm{~m}$. long and $25-50 \mathrm{~m}$. broad.

\section{Glacier Behaviour 1957-63}

Glaciological observations at Svartisen in 1957 included a study of Flatisen (Stokes, I 958, unpublished). The glacier was then about $5 \mathrm{~km}$. long, and its average width was about $\mathrm{I} \mathrm{km}$. It ended well back from the line of Glomdalen, about I,80o m. west of the Glonaaga waterfall with which it had been almost in contact in the 1890 's. The crevasse pattern was relatively simple, except near the extremely broken end immediately above the lake which had formed in front of the retreating glacier. Calving occurred regularly into the lake, though the tongue did not float. The height of the I km. wide ice cliffs ranged from 8 to $\mathrm{I} 8 \mathrm{~m}$., and the maximum sounded depth of the water adjacent to them was $26 \cdot 5 \mathrm{~m}$. Large masses of stagnant ice lay below the hanging glacier which descended from the southern end of the Snetind ridge, and all the former tributaries of Flatisen were much smaller in 1957 than in 1935 . Stokes identified four main stages of deglaciation in the area, including the " $175^{\circ}$ trim line". Between 1957 and 1962 , the actively calving front of Flatisen retreated about $300 \mathrm{~m}$. Most of the dead ice noted in 1957 had melted by 1962 , though a very large ice avalanche which occurred from the end of the hanging glacier below the Snetind ridge in $1961-62$, deposited much of the lower part of the tongue on the area formerly covered by dead ice.

In 1957 , the central section of Østerdalsisen was still very flat and free from crevasses, so that there was no difficulty in walking there. The western arm, however, was much broken, and the icebergs packed the bordering lake so tightly that little water could be seen even before it drained to Svartisdalen. When the flood happened, in August, the level of the lake fell about $60 \mathrm{~m}$. in ten days. Detailed observations at Østerdalsisen were begun in I959. In the succeeding four years the eastern arm retreated about $175 \mathrm{~m}$., and by 1963 it ended about $\mathrm{I}, 400 \mathrm{~m}$. from Svartisvatn, in a melt-water lake (Fig. 8). The position of the southern border moved $79 \mathrm{~m}$. down slope in the period 1957-63; between August 1947 and August 1963, the position of the ice margin on Burfjell dropped $5^{8} \mathrm{~m}$. vertically in shifting $\mathrm{I} 69 \mathrm{~m}$. horizontally. The completion of the flood-relief tunnel in 1959 resulted in a permanent lowering of the level of the ice-dammed lake, and a decrease of the rate cf retreat of the western arm of Østerdalsisen as calving diminished. Between 1935 and I959, however, calving had resulted in a fivefold increase of the size of the lake; in all, about $3 \mathrm{~km} .{ }^{2}$ of the glacier had broken away 
during that time. Lundqvist ( I96 I), who revisited Østerdalsisen in I96o, described the changes since his previous visit, twenty-five years before, as immense, and illustrated them with a number of photographs. He emphasized the extreme lack of morainic material at the glacier in both years.

The mean annual surface ablation at the centre of Østerdalsisen between r 960 and r963 was of the order of $7 \mathrm{~m}$.; approximately half the total occurred in July and August each year. In 1897 , the thickness of the ice overlying the present position of the eastern end of Østerdalsisen was about $25^{\circ} \mathrm{m}$.; by 1935 , this had decreased to about $200 \mathrm{~m}$. At the present

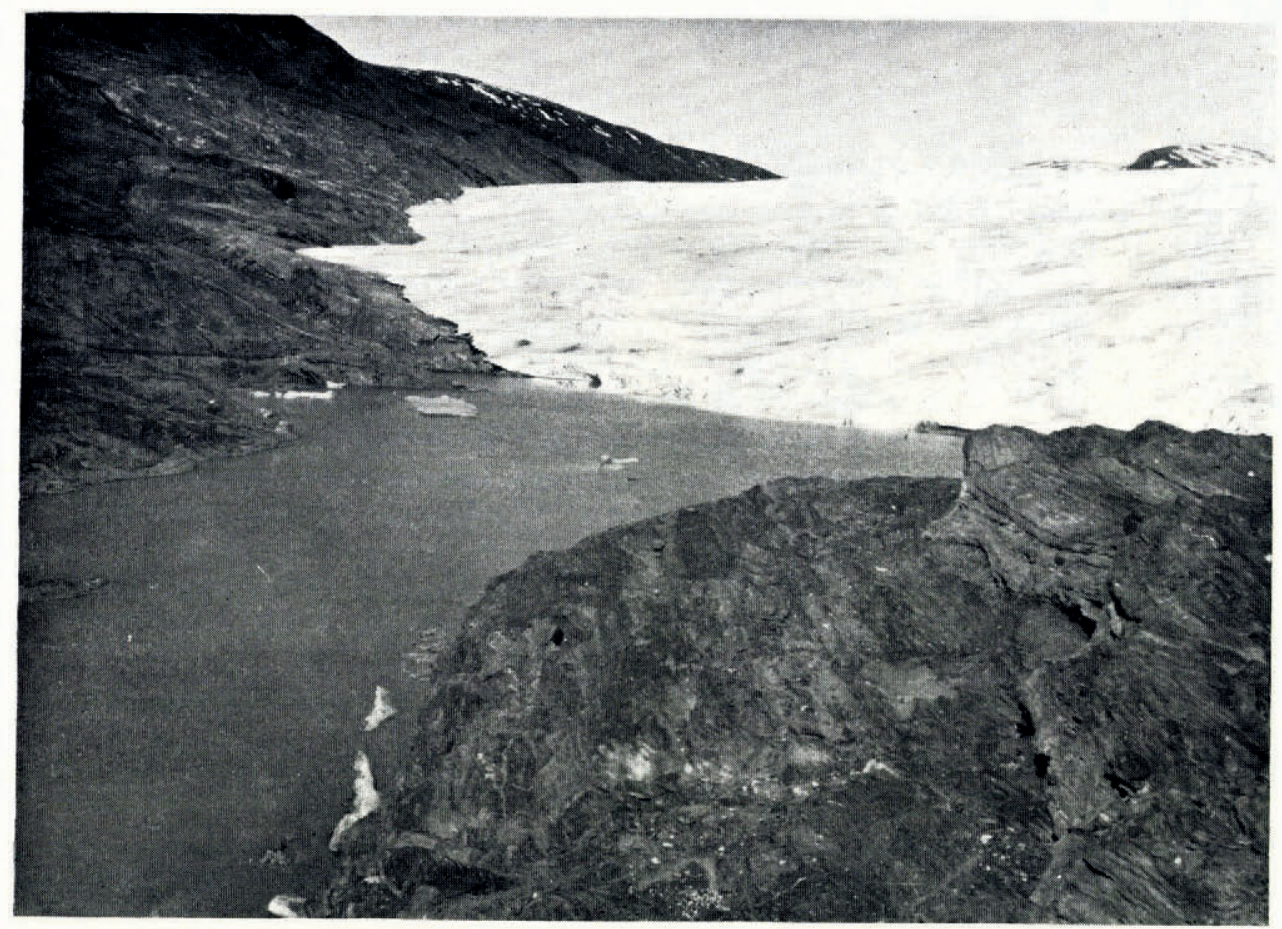

Fig. 8. The eastern arm of Osterdalsisen, I6 July I952. The glacier now ends in a melt-water lake. The "I750 moraine" on Burfjell can b? seen in the background

position of the southern margin of the glacier, a thickness of about $120 \mathrm{~m}$. of ice has melted since $1897,75 \mathrm{~m}$. of it since 1947 . Between 1957 and 1959 a great crevasse belt developed south of the ice fall of Osterdalsisen, in front of the glacier's border on Burfjell. Continued thinning of the ice above a bedrock hump seems to be the most likely cause of the feature. From I959 until $\mathrm{I}_{96}$, the crevasse belt became increasingly extensive, though a flat area remained at the foot of the ice fall. In 1962, the flow of water into the flood-relief tunnel resulted in the formation of a gorge at the southern side of the western end of Østerdalsisen, above the tunnel inlets. Frequently, large blocks of ice broke away from the sides of the gorge, and many of them were washed through the tunnel to Svartisdalen. A gorge of similar appearance also formed at the northern side of this arm of the glacier, where the main melt stream flowed from the ice into the adjacent lake. The course of the stream had been made evident in earlier years by the development of a system of concentric crevasses in the overlying ice. The crevasse pattern, which resulted from collapse of the ice into the stream course at its bed, had become increasingly extensive as the ice above the stream became thinner in succeeding years. In 
1962 , the ice became so thin that it fell into the stream, and the tunnel which previously had existed at the bottom of the glacier was replaced by a gorge.

Conditions within the accumulation zone supplying Østerdalsisen vary from year to year. In both 1957 and 1959, the zone remained snow-covered throughout the summer, and little bare ice was visible when the first heavy falls of snow occurred in late August and September. In contrast, much ice was exposed in 1960 as early as the middle of July, and by the end of August only a few isolated patches of snow and firn were to be seen, mainly in the hollows adjacent to nunataks. Similar conditions prevailed in the following year, when the disappearance of snow and firn by mid-July resulted in exposure of bare ice over almost the whole of the southern part of Østisen. In the summer of 1962 , however, ice was seen only on the steepest slopes and close to the rock outcrops; more than $3 \mathrm{~m}$. of old snow could be seen at the sides of crevasses in mid-August. In 1963 , the snow cover again persisted throughout the summer over almost the whole of the accumulation zone of Østerdalsisen, and ice was laid bare only on the steeper slopes and at the southern border. No direct relation between summer climate and the mass balance of Østisen is apparent.

In I96I, Gåbrokbreen ended above a small cliff north of the peak " 1,185 " (Davies, unpublished). Rock outcropped continuously between " 1,185 " and Blakkåtind; the ridge extended to the corrie west of the latter, and it was clear that much ice had gone from the area since 1910. Gåbrokbreen was almost completely separated from its source of supply, as a steep rock wall ran south-westwards from the slopes above Bjellådalen (Fig. 9). A narrow icefall descended this wall north-east of Blakkåtind, and some avalanching occurred over the exposed section. A large curving crack cut the lower part of the glacier from the border by "I, 185" almost to the other side, and the end of the glacier seemed to be collapsing into a bedrock depression. A detached mass of ice lay some distance below the front of Gåbrokbreen. Comparison of photographs taken in 1960 and 1961 indicated that, although relatively little horizontal change of position occurred, the centre of the glacier front became much thinner in the twelve months between the observations. Miss Davies concluded that the extensive changes of the ice cover of the Gåbrokbreen area since 1896 had resulted largely from ice stagnation.

\section{The Present Situation of the Svartisen Glaciers}

The south-eastern part of Vestisen is now almost completely separated from the rest of the ice cap by the line of peaks south of Flatisen, which today forms a nearly continuous rock outcrop. Blokkfjellbreen, the principal outlet of this part of Svartisen, ends $300-400 \mathrm{~m}$. above the bottom of Glomdalen, and is much narrower than when surveyed in I897. The ice stream which formerly was tributary to Blokkfjellbreen now hangs high above its northern side (Fig. I0). The lake marginal to Flatisen grows steadily larger as the glacier calves into it. The ice front has retreated to the eastern limit of a large rock buttress which juts from the northern valley wall almost $2 \mathrm{~km}$. from the Glomåga waterfall. The glaciers to the north, once tributary to Flatisen, hang as much as $700 \mathrm{~m}$. above the lake shore (Fig. I I). Since I935, however, the glacier south of the Snetind ridge has retreated much further than has that which descends east of Gryttind. In the northern part of Glomdalen, the glaciers from Vestisen do not go far down into the valley. Both s. Breitindbre and n. Breitindbre which occupy large, trough-like hollows cut back in the valley side, have diminished greatly since I9 Io, and both now occupy only a small part of their former channels. Thinning of Kjølbreen has resulted in separation of a large part of the glacier tongue (Fig. 12), and avalanches descend the rock slope to Kjølvatn quite frequently.

The central glacier of the three flowing towards Storglomvatn still reaches the lake, and the northern one regularly sends ice avalanches into it, principally from its northern side, which terminates on smooth rock slabs (Fig. I3). Material from some of the avalanches is 


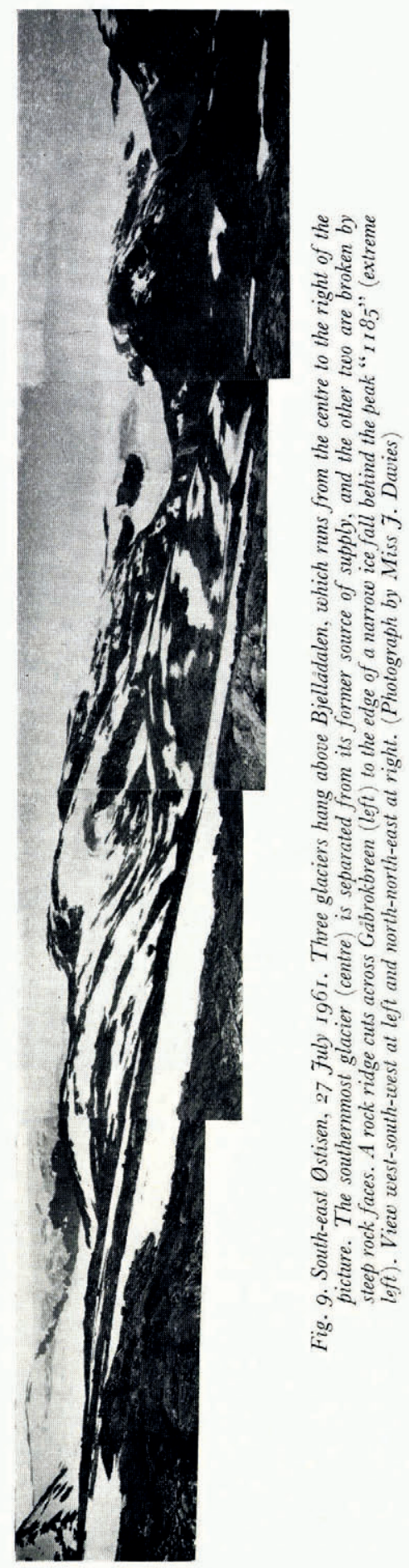


reconstituted at the foot of the slope. The eastern outlet shows the greatest changes since photographs were taken in I9I0; it ends several hundred metres from Storglomvatn as a steep, narrow tongue in a deep gorge. Clearly, the ice formerly filled a subglacial gorge, the sides of which have been exposed by ablation. The fourth glacier which descends in the direction of Storglomvatn, further north, has become much more narrow, and has retreated several hundred metres, in the last half-century. The small glacier tongues to the north of

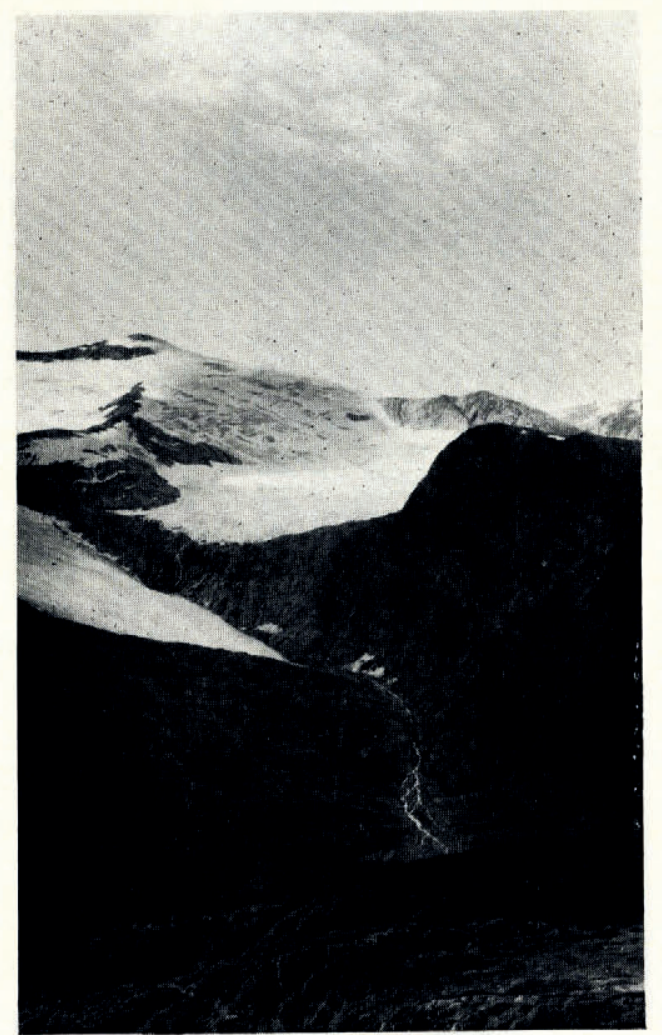

Fig. Io. South-east Vestisen, I7 August 196I. A tributary glacier hangs above the northern side of Blokkfjellbreen (left), which terminates high on the shoulder of Glomdalen. At the beginning of the century, the two ice streams united, and descended almost to the valley floor

this have retreated almost to the outer edge of the plateau from which they descended many hundred metres in earlier years. At the south-western part of Vestisen, Nordfjordbreen lies immediately above the corrie at the head of Nordfjord, and its lower end extends just over the steep slope from the plateau. Ice avalanches regularly descend the slope below the heavily crevassed, hanging tongue.

The two northern outlets of Østisen terminate at least $500 \mathrm{~m}$. south of the position indicated on the 1898 map. Much ice has disappeared north of Istind, and a valley has been revealed there. North-east of Sniptind, there has been general retreat of the ice limit in Glomdalen. The extent of retreat since 19 Io is particularly noteworthy to the north-west of Istind, where an advance of the glacier descending into Glomdalen was recorded between I $89 \mathrm{I}$ and I 9 IO (Figs. 5 and 12). Both the glacier between Sniptind and n. Kamplitind, and n. Kamplitindsbre to the south, end $400 \mathrm{~m}$. or more above the level to which they descended in 1897 . A detached 

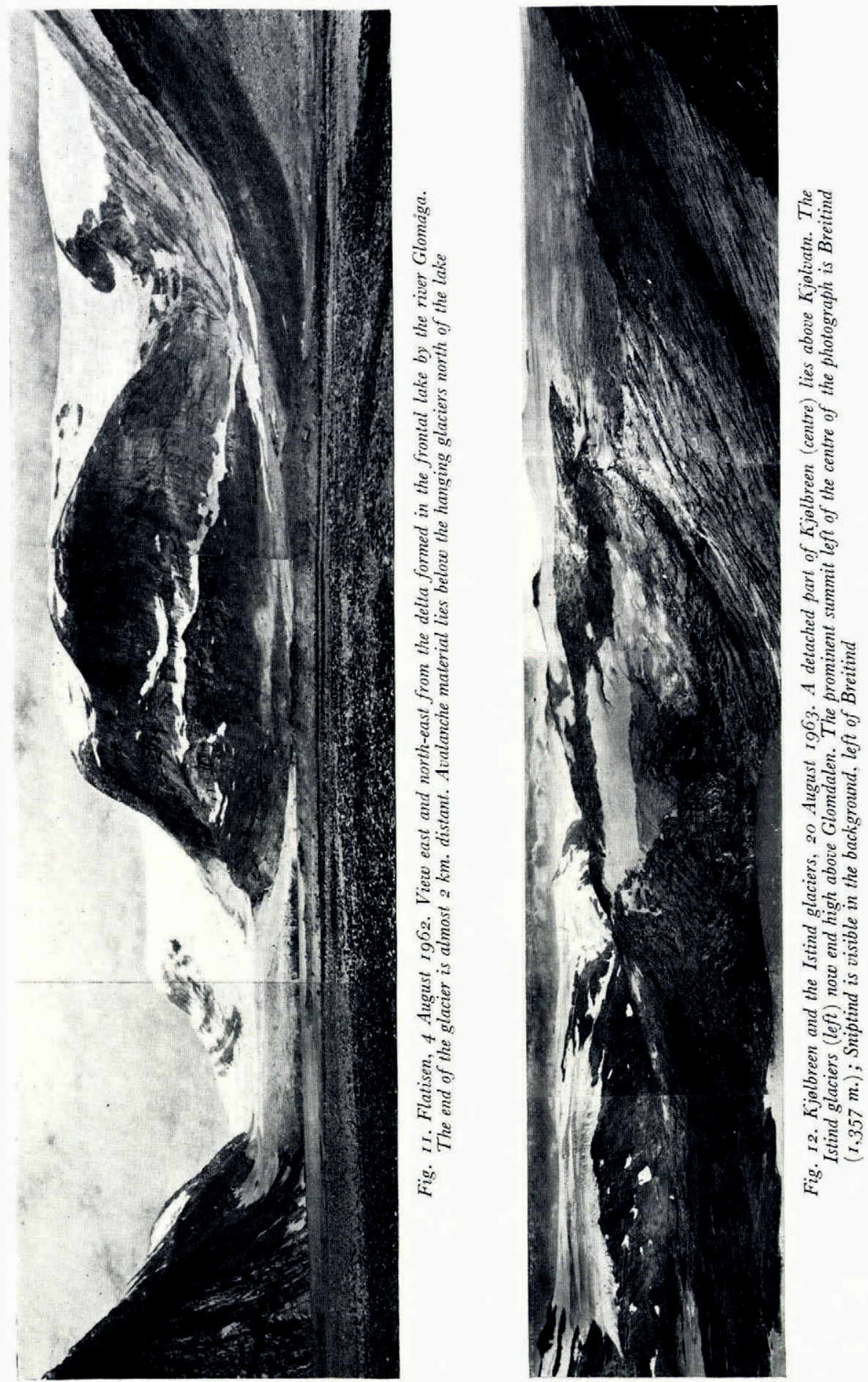

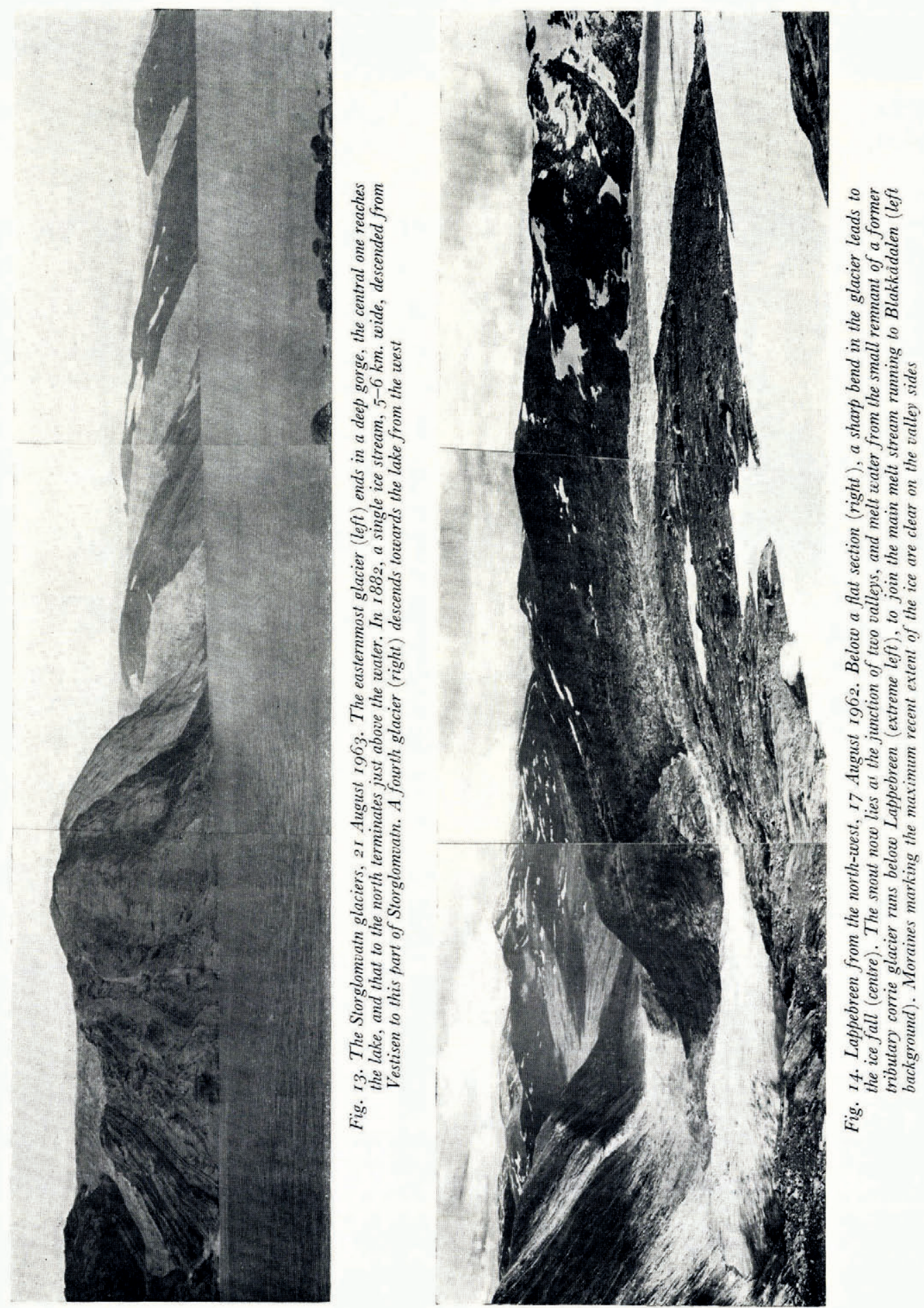
mass of ice lies south of the tongue of $n$. Kamplitindsbre, which ends above a high rock step. A partly detached ice fall lies behind the snout of the glacier, crevasses there extending almost to the underlying rock. The summit south of the glacier, and an area $400 \mathrm{~m}$. wide on the northern slopes of s. Kamplitind, have become free of ice and permanent snow since r 897 .

Østerdalsisen has suffered the greatest changes of any of the Svartisen glaciers during this century. Much rock has been revealed within the accumulation zone, as well as around the margins of the lower part of the glacier, and several large nunataks, not indicated on the 1897 map, rise to a considerable height above the ice surface in this area. To the east, most of the ice cover around Blakkåtind has disappeared since the beginning of the present century. Two small glaciers hang above the corrie west of the mountain, but the ice mass which feeds them has become separated from the main part of Østisen. The southernmost of the three glaciers which formerly descended to Bjellådalen now is merely a stagnating mass of ice, detached from its original accumulation area on Østisen. The central glacier in Bjellådalen descends from the north-west by way of an ice fall, and is fed also by a narrow ice fall and a hanging tributary at its southern side. In I896, this glacier presented a continuous front more than $2 \mathrm{~km}$. wide to the head of the valley; now it ends several hundred metres behind the 1896 position, and is very much thinner than at that time. The northernmost glacier in Bjellådalen is broken by a steep rock cliff, which gives rise to an ice fall similar to those of Gåbrokbreen and the central glacier; it ends at a much higher level than it did in I 896 (Fig. 9).

Lappebreen terminates about $\mathrm{I}, 200 \mathrm{~m}$. further west than in $\mathrm{i} 896$, almost where the lowermost bend of its course formerly was situated (Fig. 14). The corrie glacier which joined it at this point in 1896 , and which had retreated $800 \mathrm{~m}$. by 1910 , now exists only as a small, detached piece of ice below a hanging tongue, $2 \mathrm{~km}$. from the former junction. Melt water from this ice, however, still flows down the valley, and disappears beneath the lower part of Lappebreen. The upper section of the latter is flat and relatively free from crevasses; the glacier there widens out below the hanging remnant of a former tributary. An ice fall still coincides with the right-angle bend below this part of the glacier. Fingerbreen has retreated a little less than one kilometre since 1896 , and most of the ice has gone from the valley side to the north. The glacier is flat and free from crevasses for much of its length, and slopes gently to a tapered snout. The nunataks at its head, mentioned by Marstrander (I 9 I I [a]), are considerably larger than in 1910 , and a small ice fall about $800 \mathrm{~m}$. wide lies between them and the end of the northern wall of the valley containing Fingerbreen. A large amount of moraine lies on the southern side of the glacier, probably provided as Marstrander suggested by the hanging glaciers above, all of which now are much smaller than in the past.

The nunatak peaks and bordering mountains of both Vestisen and Østisen today rise to a much greater height above the adjacent ice surface than that shown on the I : roo,ooo topographic maps, and all are much more extensive. It is plain that the ice cover on the two plateaus has become many metres thinner during the course of the twentieth century.

\section{Conclusion}

Observations at Svartisen throughout the last ninety years have shown that the glaciers there have been in a state of retreat for most of the period. Although minor advances have occurred, they have been only temporary interruptions of the overall decrease of the ice cover. The decay of the glaciers has been particularly rapid since the 1930's, and the areas of accumulation on both plateaux have been affected to a marked extent. Thinning of the ice above the plateau borders has resulted in the separation of some of the outlets from their former sources of supply; today, a number of stagnating ice masses lie around the outer edges of Vestisen and Østisen, and hanging ice falls or tributary glaciers are fairly common. Many of the glaciers formerly occupied depressions, or rock basins, in the valleys around the plateaux, and retreat of the ice along these has been accompanied by the formation and growth of 
marginal lakes. Both separation along rock ridges and calving into frontal lakes have contributed to the rapid recession of the ice limit at Svartisen.

\section{Acknowledgements}

The annual Cambridge Expeditions to Svartisen have received financial assistance from the Royal Geographical Society, the Mount Everest Foundation, and the Tennant, Scandinavian and Gino Watkins Funds of the University of Cambridge. During the period I $_{95} 8-63$, the author held a State Studentship of the Norwegian Government, the Tennant Studentship of the University of Cambridge, and a D.S.I.R. Studentship, and received grants from the Norwegian-British North Sea Foundation and the University of Sheffield.

Without the help and encouragement of the late W. V. Lewis, the programme of observations at Svartisen would not have been initiated. Continuation of the studies has benefited from the advice and assistance of Dr. G. de Q. Robin, Glasiolog Olav Liestøl, Professor J. A. Steers and Professor Kaare Strøm. Great help in the field has been given by all members of the Svartisen lixpeditions, particularly C. J. Rhodes, H. C. Fitzwilliams and R. G. Bennett, leaders of the I960-63 parties. Miss J. Davies and J. C. Stokes have kindly made available the results of their own studies at Svartisen.

Norges Geografiske Oppmåling provided access to the unpublished report by Kaptein O. Paulsen, and Norsk Polarinstitutt to that by A. Bergersen. The acting editor of Norsk Geografisk Tidsskrift gave permission for copies of photographs originally published in that journal to be reproduced here (Figs. 2, 6 and 7). Many photographs taken by the late R. Marstrander were kindly lent by his widow and nephew; two are reproduced in this article (Figs. 4 and 5). Karl Johan Westermark supplied an immense amount of information about local conditions, and about changes at Svartisen since 1947, and Anton Svartisdal, who provided hospitality on numerous occasions, has made regular observations of the annual snowfall in the last few years. T. W. Freeman made many helpful comments about the manuscript. Miss E. A. Lowcock drew Figures I and 3 .

MS. received 26 May 1964

\section{REFERENCES}

Bergersen, A. Unpublished. En undersokelse av Svartisen ved Holandsfjord 1950-51. [Dissertation for examination in physical geography, University of Oslo, 1953.]

Dass, P. 1958. Nordlands trompet. Oslo, Aschehoug. [First published I 739.]

Davies, J. Unpublished. Gåbrokbreen: an outlet glacier of south-east Østisen (Svartisen). [Student dissertation, University of Cambridge, r 962.$]$

Fægri, K. 1935. Forandringer ved norske breer 1933-34. Bergens Museums Arbok, 1934, Nr. I I.

Fægri, K. [1950.] On the variations of western Norwegian glaciers during the last 200 years. Union Géodésique et Géophysique Internationale. Association Internationale d'Hydrologie Scientifique. Assemblée générale d'Oslo, I9-28 août 1948. Procès-verbaux des séances. Tom. 2, p. 293-303.

Geikie, A. 1882. Geological sketches at home and abroad. London, Macmillan.

Granlund, E., and Lundqvist, G. 1936. Nảgra iakttagelse från en resa i Helgeland sommaren i 935. Norsk Geografisk Tidsskrift, Bd. 6, Ht. I, p. I I-I 4 .

Hoel, A., and Werenskiold, W. 1962 . Glaciers and snowfields in Norway. Norsk Polarinstitutt. Skrifter, Nr. II4.

Holmsen, G. 1949. En ny bredemt sjø i Svartisen. Norsk Geografisk Tidsskrift, Bd. 12, Ht. 4, p. I53-67.

Jensen, C. i 935 . Fra fjord og fjell i Helgeland. Norske Turistforenings Arbok, i 935, p. 1 44-59.

Liestøl, O. I 956. Glacier dammed lakes in Norway. Norsk Geografisk Tidsskrift, Bd. I 5, Ht. 3-4, 1955-56, p. 122-49.

Liestøl, O. 196o. Discovery of a tree stump in front of Engabreen, Svartisen. Norsk Polarinstitutt. Arbok, 1960, p. $64-65$.

Lundqvist, G. 1961. Österdalsisen av Svartisen. Geologiska Föreningens i Stockholm Förhandlingar, Bd. 83, Ht. 1, No. 504 , p. I-IO.

Marstrander, R. I91 I[a]. Svartisen. Strøgets morfologi og bræerne. Archiv for Mathematik og Naturvidenskab, Bd. $3 \mathrm{I}$, Nr. 8, p. $\mathrm{I}-40$.

Marstrander, R. 191 I [b]. Svartisen, dens geologi. Norges Geologiske Undersøkelse, Nr. 59, Nr. 4, Aarbok, 191 I, p. 1 -31.

Paulsen, O. Unpublished. Beskrivelse til oppmàling af Mo herred. [Report in archives of Norges Geografiske Oppmåling, I 899.] 
Rabot, C. 1898. Au Cap Nord: itinéraires en Norvège, Suède et Finlande. Paris, Hachette.

Rabot, C. 1899 . Les variations de longueur des glaciers dans les régions arctiques et boréales. Archives des Sciences Physiques et Naturelles, Tom. 8, No. 10, p. $32 \mathrm{I}-43$.

Rabot, C. 1935. Fjellturer og brevandringer i 8o-ärene. Norske Turistforenings Arbok, 1935, p. 123-34.

Rekstad, J. 1892. Om Svartisen og dens gletschere. Norsk Geografisk Selskabs Aarbog, Bd. 3, p. 71-90 Rekstad, J. 1893. Beretning om en undersogelse af Svartisen, foretagen i somrene 1890 og i 891 . Archiv for Mathe-
matik og Naturvidenskab, Bd. 16, p. 266-32 I.

Rekstad, J. I900. Om periodiske forandringer hos norske bræer. Norges Geologiske Undersogelse, No. 28, No. 4, Aarbog for 1896 til I 899 , p. I-I 5 .

Rekstad, J. I91 I. Forandringer ved norske bræer i aaret r9o8-1909. Bergens Museums Aarbog, i910, Nr. 4.

Rekstad, J. 1912. Die Ausfüllung eines Sees vor dem Engabrä, dem grössten Ausläufer des Svartisen, als Mass der Gletschererosion. Zeitschrift für Gletscherkunde, Bd. 6, Ht. 3, p. 2 I $2-14_{4}$

Rekstad, J. 1915. Forandringer ved norske bræer i året $19^{1} 3^{-1} 4$. Bergens Museums Arbok, 1914-15, Nr. 7. Richter, K. I936. Gefügestudien im Engebrae, Fondalsbrae und ihren Vorlandsedimenten. Zeitschrift für Glet-
scherkunde, Bd. 24, p. 22-30.

Rogstad, O. 1942. Vare breers tilbakegang. Norsk Geografisk Tidsskrift, Bd. 9, Ht. 4, p. 129-57.

Rygh, K. 1935. Pioner turer over Svartisen. Norske Turistforenings Arbok, 1935, p. 135-43.

Seue, C. de. 1876 . Undersøgelse af Svartisen og temperaturforhold i enkelte af de Nordlanske fjorde. Nyt Magazin for Naturvidenskaberne, 2 Ide Bd., Ht. 3, p. 229-70.

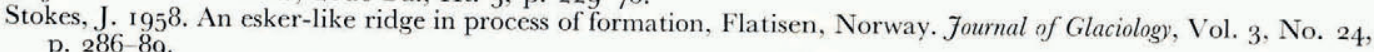
p. $286-89$

Stokes, J. Unpublished. Flatisen. [Student dissertation, University of Cambridge, 1958.]

Vargas-Bedemar, E. R. von. 1819. Reise nach dem Hohen Norden durch Schweden, Norwegen und Lappland in den Jahren $1810,1811,1812$ und 1814 . Frankfurt am Main, Verlag der Hermannschen Buchhandlung 2 vols. 